$18 \mid 2014$

NOVECENTO... E DINTORNI

Da Torino a Parigi: Laura Malvano storica e critica d'arte

The Pleasures and Perils of Curating an Exhibition: Miró at the George R. Gardiner Museum of Ceramic Art in Toronto

Les péripéties d'une exposition: Miró au George R. Gardiner Museum of Ceramic Art à Toronto

Soddisfazioni e difficoltà legate all'organizzazione di una mostra: Miró al George R. Gardiner Museum of Ceramic Art a Toronto

\title{
Anne McPherson
}

\section{OpenEdition}

\section{Journals}

Electronic version

URL: http://journals.openedition.org/cei/1997

DOI: 10.4000/cei.1997

ISSN: 2260-779X

\section{Publisher}

UGA Éditions/Université Grenoble Alpes

\section{Printed version}

Date of publication: 30 March 2014

Number of pages: $247-254$

ISBN: 978-2-84310-268-4

ISSN: 1770-9571

Electronic reference

Anne McPherson, "The Pleasures and Perils of Curating an Exhibition: Miró at the George R. Gardiner Museum of Ceramic Art in Toronto", Cahiers d'études italiennes [Online], 18| 2014, Online since 30 September 2015, connection on 27 March 2021. URL: http://journals.openedition.org/cei/1997 ; DOI: https://doi.org/10.4000/cei.1997 


\title{
THE PLEASURES AND PERILS OF CURATING AN \\ EXHIBITION: MIRÓ AT THE GEORGE R. GARDINER \\ MUSEUM OF CERAMIC ART IN TORONTO
}

\author{
Anne McPherson ${ }^{\mathrm{I}}$
}

\section{The opportunity and the idea}

In 1997 I was invited by the director-curator of The George R. Gardiner Museum of Ceramic Art, as it was then named, to present the museum's chief exhibition for the year 2000. Of course I was thrilled at the prospect, and when she asked if I had any ideas for it, I immediately said "Miró". She looked very doubtful and suggested Picasso. When I said no, it should be Miró, she bargained, Picasso and Miró? I insisted that Miró was the artist we must have, and after I had shown her some photos of his work, she agreed.

A few years before I had wandered into a small exhibition space on the Ramblas in Barcelona, and discovered an extraordinary, somewhat disturbing, but at the same time amusing, assortment of ceramics. It included not only the usual shapes of plates — large chargers, really—vases and tiles, but sculptures representing human forms, built of oddments that could have been picked up from a pile of castaways at the side of the road (some of them were); and many of these painted in what first appeared to be aimless graffiti, though first glances are deceiving. A very obliging and well-informed woman introduced me to the ceramic work of Miró. After the first moments of surprise, it became obvious that this was indeed Miró in another medium. I had seen his work in bronze, had seen the great Labyrinth at the Fondation Maeght in St-Paul-de-Vence; but these smaller, unassuming works delighted me on account of their

I. Anne McPherson was the curator of Miró: Playing with Fire, which was presented at The Gardiner Museum, Toronto, Canada from 7 September 2000-7 January 2001. 
playful insouciance, almost as though Miró were taking a holiday, just as he seemed to do long ago in his farmyard in Montroig.

Seeing that first tantalizing exhibition of ceramics, I began to wonder if it might be possible to introduce this astonishing work to a Canadian audience.

\section{The perceived drawbacks}

The Gardiner Museum in Toronto was at that time a new, small museum. (Since then it has shortened its name and expanded its space and collections.) The collections, beautiful and well presented, were almost entirely historical, with the emphasis on European ceramics of the eighteenth century, and two smaller collections of Renaissance maiolica and preColumbian terracottas. There had been a number of contemporary exhibitions, but one of this size and importance had never been mounted entirely on our own.

The first potential difficulty that came to mind was, since very few museums had ever heard of us, how were we to borrow significant works? Within the Gardiner walls the second difficulty was, since no one seemed to know about Mirós ceramics, would the board take on this expensive undertaking? In terms of the museum's budget, this would be a blockbuster, but blockbusters are comprised of famous works by familiar artists, and are expected to make money. The question of who would be the sponsors who would help to defray the costs, and the visitors who would be attracted to the exhibition, came later on. At that time Gardiner budgets were drawn up to show expenses, but not potential revenue.

The director, with her usual persuasive competence, convinced the board to approve the exhibition. The other problem-who would lend to us - was for me to solve.

\section{Meetings with extraordinary collectors in unusual settings}

I cannot remember now what came first, the search for people who would lend, or the choosing of those works I would most love to exhibit together. I suspect it was a see-saw between the two, but from the beginning I knew that if I could beg just a few major works and supplement with others, the exhibition would be worthwhile. On the other hand, if I were only able to come home with a few, shall we say, painted pebbles, vases you could hold

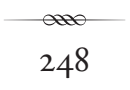


in your hand, then no exhibition could go on. With the help I received from those closest to Miró and his work, I was able to borrow everything I asked for, and only had to relinquish a few important additions later on (see below).

I began by considering all the images I could find in print. Most of the major exhibitions of Mirós work did not contain any ceramics, so the big international catalogues were useless. There had been small catalogued exhibitions of his ceramics, but these were difficult to find. The most comprehensive book was published by the Galerie Maeght in Paris, but I had almost completed my selection when I found it there.

Among all the images I was able to look at, there were certain constants: the forms of vases, platters, tiles and shards appeared regularly. There were forms of women with hollowed-out vaginas, faces of monsters, graffiti of creatures with fierce teeth. There were sculptured heads, figures built from odd shapes that Miró picked up from the ground while out walking, or from the déchetterie behind the potter's studio. Mirós imagination seemed to lead him in two directions: in using clay he demonstrates his freedom to paint, to form, to build, and to leave things alone; at the same time he shows the remarkable cohesion he was able to achieve with his mentor/ potter/friend Josep Llorens Artigas. For it was Artigas who taught him everything he came to know about clay, and who was his collaborator in all ceramic work until Artigas' death.

The exhibition would not have been possible without the help of Artigas' son, Joan Gardy Artigas, who worked along with his father and Miró, starting out as a young apprentice, and finally taking over from his father. In his beautiful house and studio in the hills above Barcelona, where potters and artists come to work and study, we talked about the exhibition, about Miró, and Joan's privileged experience of those years in the 70 and early 80 s when the two men created public murals together. From Joan I was able to borrow pieces created by Miró/Artigas, and several handsome vases made by Artigas himself. I left with the names of several people to contact, both private lenders and gallery curators.

Joan Gardy Artigas was my introduction to some of the most important galleries, museums and private collectors. I would mention his name, and immediately I was taken seriously. In one case I was told, Joan told us to lend to you. Without that splendid reference, I am sure I would have been turned away.

Then the net spread: once I mentioned that such-and-such a gallery was lending to the exhibition, others came along. There is of course a certain cachet in being part of a good museum exhibition; if you are a 
private collector, it adds to the esteem in which your pieces are held (as well as possibly increasing their value). In all, I was able to borrow from 5 collections in Spain, 4 in France, I in Switzerland, 4 in the United States. There are no ceramics by Miró in either public or private collections in Canada, as far as I know.

The most thrilling part of this dizzying shopping expedition occurred when I came to the notice of the family. ("Joan told us to be good to you.") I contacted Joan Punyet Miró, the grandson who looks after the artistic side of the family estate. He invited me to come to Mallorca for the weekend, to choose from the family collection the works I would like to borrow. We met at the airport in Barcelona \& flew to Palma; from there to Mirós own house in the hills outside the city, which now belongs to this grandson - the other grandson has a house on the estate, and Mirós daughter Dolores lives just below. From the balcony I could look down at the museum built by Miró to house his collection, and beyond that out to sea. Sitting in the house I was surrounded by work of other notable artists, as Joan Punyet brought out some of the family's ceramic collection. I could borrow whatever I wished. We carried the chosen pieces out on to the grass to photograph; once finished, I was taken to dinner high up in the hills, driven at terrifying speed in the most exotic sports car I have ever sat in.

The next day I was introduced to the intimate and solitary Miró. When he first bought this splendid hillside property he used the old farmhouse there as his studio. He added a house for himself and his wife, and-his long-held dream — a large, tall studio filled with light, its windows facing the sea. Other buildings came after, but it was here that Miró spent all his time, painting and thinking. (He made no ceramics here; these were accomplished in Artigas' workshop in Barcelona.)

Both studios, the old and the new, have been kept as he left them. A gallery runs around one end of the new one, holding large work tables with brushes, paints, pens and pencils, and the usual paraphernalia. Also on the tables and shelves are fanciful scatterings of small objects- the sort of things you or your grandchild might pick up on the beach, in an old curiosity shop, or at a craft bazaar. Some of them may have made their way into Mirós work: I suppose this might be a subject for a dissertation one day. Or they may have been there just because he liked them, these homely, everyday things.

It is such a contrast to look over the mezzanine railing into the great open space below. Large unfinished canvases are stacked there, and there is a single chair for the artist, far enough back from his easel that he can sit 
and contemplate the next strokes on the canvas before him. His presence is vivid: it seems as though he has just gone out for a quick coffee and will be coming back soon.

Instead, he may have gone next door to the old farmhouse whose walls are covered with graffiti sketches, many of which reappear in finished works. At the top of the stairs is a closet-size room, big enough for one chair, where Miró used to go and meditate, away from paint, colour, images and all worldly gatherings.

This was the Miró I was introduced to slightly, who seemed so remote from his great canvases and totemic sculpture, and yet not so distant after all. What I was looking into-not very deeply it is true-was the bottomless source from which he drew up his whimsical, furious, adorable, ironic, metaphysical thoughts and images, and transformed them into art. Mirós creations are not surface-formed: they come from the deep, his ceramics just as surely as any other work he made.

\section{The burden of transport}

While all the lenders were very agreeable about letting their works travel to Canada, they naturally had certain restrictions. We had a request from a transport company in Madrid to carry the Spanish pieces. They had moved art work for some reputable museums in Madrid, and when I questioned their method of packing and trucking, they flew me down from Toulouse, put me in a hotel, and took me to the company's warehouse to show me the materials they used, and how they prepared them to fit exactly the different artifacts they packed. When I came back and spoke to one of the lenders in Barcelona I was told that they preferred to use the local shipper they knew. The son of the owner of the Madrid firm even paid them a visit to reinforce what I had been told, but the Barcelona lender would not budge - civic or Catalan pride, I expect.

In Paris we had asked a number of important sources for the name of the shipper they used, and were satisfied that this was the best firm, long established, with a very good reputation. One of our lenders refused to use this firm, and insisted on having a different one. The other lenders wanted the older, well-known one. So we had 2 packers and 2 shipments out of Paris, adding more to our cost. In the end we received 6 shipments in all. One sculpture, from Chicago, was sent alone, the only object in the truck.

While all these arrangements were being discussed and decided, the museum had undergone some significant changes. From the time I began 
to think about the exhibition till this point there had been 3 different directors. The first, who proposed the idea, took a year's leave. The second, a I-year replacement and long-time curator, was enthusiastic and supportive; I was given free rein to draw up the exhibition, just putting her in the picture from time to time. If I could solve problems myself, she was delighted not to have to do so. The third person, a permanent appointment, had never taken charge of a museum before. She was naturally very cautious about every step that was taken, particularly as it related to finances.

I had secured agreement from the Fundacio Miró in Barcelona to borrow 3 of the notebooks, showing many sketches that appeared later on the ceramics. In Madrid I had received permission from the Reina Sofia Museum - in fact from the queen herself they told me-to borrow 2 bronzes that were very close in form and intent to the ceramic figures I was showing. The condition for borrowing from both museums was that the Gardiner should have a guard on duty 24 hours a day. We did not have this security; rather, when the museum was closed for the night we had an alarm system, and a security company sent people to check the building every few hours.

When I told the new director what was required, she gave me a choice: we could spend money either on the upgraded security, or on a catalogue. Astonished that such a choice would have to be made, I had to write reluctantly and thank Her Majesty for the gracious offer, and hope that we might be able to do something with her fine museum in the future. I regretted greatly having to give up the bronzes, but even more I was sorry to be unable to show Miró's first thoughts in his sketchbooks, images that appeared so insistently in his ceramics.

\section{The catalogue}

The course of producing the catalogue ran smoothly, for the most part. All the people invited to contribute to it accepted. There was Joan Punyet Miró, Joan Gardy Artigas, the director of the Fundació Miró, a noted Canadian art critic, an American writer on ceramics who showed the influence of Miró on American master ceramists, and myself.

For my part, the pleasure of writing was preceded by the (even greater) pleasure of searching for Mirós footsteps. I had been to Gallifa, to Mallorca. I went to the fabulous Museu Nacional d'Art de Catalunya in Barcelona, where it was said Miró went every Sunday that he could, to look at the frag- 
ments and frescoes taken from Romanesque Catalan mountain churches, and reinstalled there. I found some of these churches, a few with stone carvings that clearly sang out, "Miró was here!" In the cathedral in Girona the II-I2th century Creation tapestry could have been signed "Miró", so much did its strange creatures resemble the contemporary artist's.

I found links to his frequently repeated woman-with-exposed-womb figure. In Ireland there was the Celtic sheela-na-gig demon or goddess, so Miró-like in temperament that I wondered if he had ever seen her. On the beatific side, Laura Malvano pointed out the similarity between Mirós women and Piero della Francesca's Madonna del Parto. (We talked often about this exhibition when I was in Paris. I was sorry she didn't come to Canada to see it.)

\section{The last hurdles: anxieties and solutions}

\section{The design}

Designing a museum exhibition is not as simple as it might appear. You cannot just remove some works from the shelves, put them away and install a new group in their places. We had invited a prominent architect with an interest in ceramics to do the overall design. He came with enthusiasm, looked about, went away and thought about it, came back again. He said that he was stumped: the only idea that came to mind was suggested by a hair salon in New York where he'd had his hair cut. The chairs were separated by a curtain that undulated serpent-like through the salon. We decided to try it, and with something like Ioo metres of terracotta-coloured raw silk, transformed the inner part of the exhibition space. Everyone loved it, one surprise following another.

\section{Attracting the public}

With a new director, uncertain as to how to position the museum, and a major exhibition that needed an audience to help pay for it, marketing became a prominent issue. An outside marketing firm had been hired, who as it turned out had no idea of the nature of the museum or the people likely to attend. It was a product to sell, just like any other. The director sent me their several suggestions for catchy titles and slogans for the exhibition, all of which turned my blood cold. I received these while on holiday in Ireland, and I recall standing inside a telephone pillar box 
in Donegal with the rain coming down outside, arguing with the director against all the proposals. I said I couldn't live with any of them. She for her part wanted the matter solved, and asked me to choose one. I said I would not, and that furthermore, the Miro family would never stand for any of them. (As it turned out, Joan Punyet Miró said that if we used any of them, the family would pull out of the exhibition.) The marketing group was replaced.

\section{Attracting the donors}

I had nothing to do with this part of the work for the exhibition, except once. I remember sitting in the lounge of the grand Hotel Colón in Barcelona, where Miró always stayed when he came to town, and listening while a potential donor, a ceramics manufacturer, made a proposal I was to take back to the museum. In exchange for a donation they wished to have a small exhibition of the factory's work alongside ours. I tried to hide my horror at the idea, thinking of how much Miró would have disliked this work, which had nothing whatever in common with his own. In the end a compromise was worked out by the museum.

\section{A week of celebration}

Finally everything came together, and we were ready. We had invited Mirós daughter and grandson, Joan Gardy Artigas, the director of the Fundació Miró and the curator of the Museum of Ceramics, from Barcelona, to come for the week. Two important collectors joined us from Paris. We held 2 vernissages, followed by 2 grand dinners. On another night we were invited to the home of a Toronto collector of ceramics, for the grandest evening of all. The chef from the Four Seasons catered the dinner. When the dessert plates arrived, they were decorated Miró-style — faces, graffiti and all.

We held a day-long symposium, which was well attended. The press came and reviewed enthusiastically. And the public arrived, and loved Miró and all his works. 